\title{
sciendo
}

\section{LitTLE OWL Athene noctua SURVEY IN THE AREA OF ULCINJ (S MONTENEGRO) IN 2015}

\section{Popis čuka Athene noctua na območju Ulcinja (J. Črna gora) leta 2015}

\author{
IVAN KLJUN ${ }^{1}$, Dejan BORDJAN ${ }^{2}$
}

1 DOPPS - Društvo za opazovanje in proučevanje ptic Slovenije, Tržaška cesta 2, SI-1000 Ljubljana, Slovenija, e-mail: ivan.kljun@dopps.si

2 Oddelek za gozdarstvo in obnovljive gozdne vire, Biotehniška fakulteta, Univerza v Ljubljani, Večna pot 83, SI-1000 Ljubljana, e-mail: dejan.bordjan@ gmail.com

\begin{abstract}
Between 29 Mar and 10 Apr, 2015, a Little Owl Athene noctua survey was carried out using the playback method in the southern part of Montenegro. The study area was situated between the town of Ulcinj and the Bojana River delta. A total of 55 calling males were registered at 26 survey points with a maximum of 4 calling males per survey point. Considering the low response rate of the Little Owl, its local population was estimated at be 55-110 calling males. This study presents the first systematic survey of the Little Owl in Montenegro.
\end{abstract}

\section{Introduction}

Little Owl Athene noctua is a transpalearctic species covering Central Europe, the Mediterranean, the Middle East and through Central Asia reaching China. A part of the species' range is located in Ethiopia and in the southern part of the Arabian Peninsula (BirdLife International 2017). In Central Europe, the species mainly occurs at low altitudes (up to $600 \mathrm{~m}$ a.s.l.). It is a species of open-country and avoids dense forests and other types of dense vegetation (CRAMP 1985). It nests in tree cavities, rock crevices and buildings. One of the limiting factors for the expansion of Little Owls is the limited number of suitable nesting sites
(VAn Nieuwenhuyse et al. 2008). Perching spots for hunting and a spot for roosting during the day are also important. The availability of grassland and arable land is beneficial but not obligatory for its occurrence (ŻMIHORSKI et al. 2009).

Generally, the population of Little Owl is nonthreatened (BIRDLIFE INTERNATIONAL 2017), but some local European populations suffered great declines in the last 60 years (CRAMP 1985; VAN NieUwenhuYse et al. 2008) and in some areas populations decreased substantially, with populations in Denmark, for example, on the brink of disappearance (SUNDE et al. 2009). The species is a resident in Europe (BIRDLIFE INTERNATIONAL 2017) and considered a regular breeder in Montenegro (STUMBERgER et al. 2008, SAVELJIĆ \& JovićEvić 2015). While ample data are at hand on the breeding, migrating and wintering waterbirds and raptors in the wider Bojana River delta area, including salt pans at Ulcinj Solana (STUMBERGER et al. 2008, SACKL et al. 2016), several other species of birds have not been included in systematic surveys of the area. There are 1-2 breeding pairs of Little Owls nesting in buildings at Solana (STUMberger et al.2008), while the estimate for the wider Bojana delta is $>18$ breeding pairs (Schneider-Jacoby et al. 2006). The data leading to this first estimate was collected in the Bojana delta during systematic surveys of other species and area surveys of rare species, especially during the surveys within the Rapid Assessment of Birds in the Bojana-Buna Area in 2004 (Schneider-Jacoby et al. 2006). The majority of data were collected during daytime surveys of different species and sites within the Bojana delta, but some were also collected during night surveys of other species, specifically Scops Owl Otus scops, European Nightjar Caprimulgus europaeus and Baillon's Crake Zapornia pussila. No systematic survey of Little Owls was carried out in this area. Our aim was to survey the population of Little Owl between the town of Ulcinj and the mouth of the Bojana River (S Montenegro).

\section{Study area and methods}

\subsection{Study area}

The study was conducted in the southern part of Montenegro, between the town of Ulcinj and the 


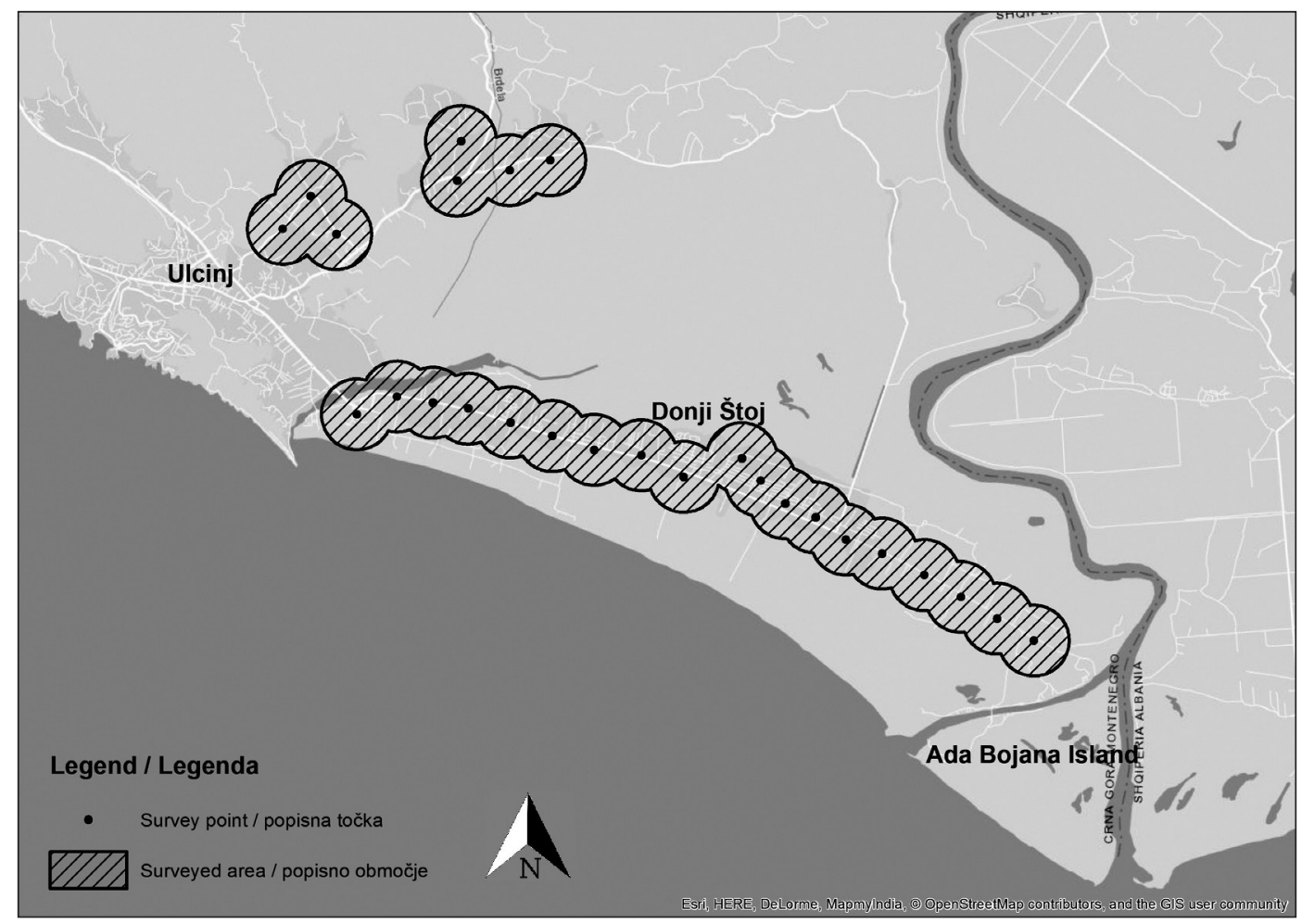

Figure 1: Map of the study area between Ulcinj and the Bojana River delta. The survey points are presented as black spots, while the surveyed area is marked as a hatched polygon.

Slika 1: Karta raziskovanega območja med Ulcinjem in delto reke Bojane. Popisne točke so označene s črnimi pikami, popisano območje je označeno kot šrafiran poligon.

Bojana River delta (UTM CM53, CM54, CM63 and $\left.\mathrm{CM} 64 ; 41^{\circ} 54.5^{\prime} \mathrm{N} 19^{\circ} 17^{\prime} \mathrm{E}\right)$. The survey points were located in the area of Stoj and suburbs of Ulcinj. Štoj is approximately $10-\mathrm{km}$ long stretch of hinterland beyond the Velika plaža (Long Beach), a $12 \mathrm{~km}$ long stretch of sandy beach. It also includes a $7 \mathrm{~km}$ long tourist village Donji Štoj and a smaller Gornji Štoj. The beach of Velika plaža is heavily visited in the summer months. The size of the surveyed area was $15.4 \mathrm{~km}^{2}$ and calculated as the surface covered by the $500 \mathrm{~m}$ detection radius around the survey points (JoHnson et al. 2007). The surveyed area is a mosaic of settlements, wet and moist meadows, salina, swamps, small-scale agriculture, scattered orchard and vineyard plantations and mostly fragmented stands of Willow Salix sp., Poplar Populus sp. and Alder Alnus sp. forests (SCHWARTZ 2010).

\subsection{Methods}

We used the playback method as described by JoHnson et al. (2007). Initially, we determined 26 survey points which were more than $500 \mathrm{~m}$ apart, with two exceptions that were 400 and $491 \mathrm{~m}$ apart. The Little Owl in the Mediterranean region has its peak in vocal activity at the end of March and the beginning of April (Johnson et al. 2007). Therefore, we decided to conduct the fieldwork in the nights of $29^{\text {th }}$ March, $2^{\text {nd }}$ and $10^{\text {th }}$ April 2015. We chose calm and clear nights with no or little wind, as weather conditions could affect the vocal activity of the owls (Zubergoitia \& Campos 1998). The surveys started at sunset and finished around 23:00. For every Little Owl we recorded the approximate direction in order to minimize count replications. 


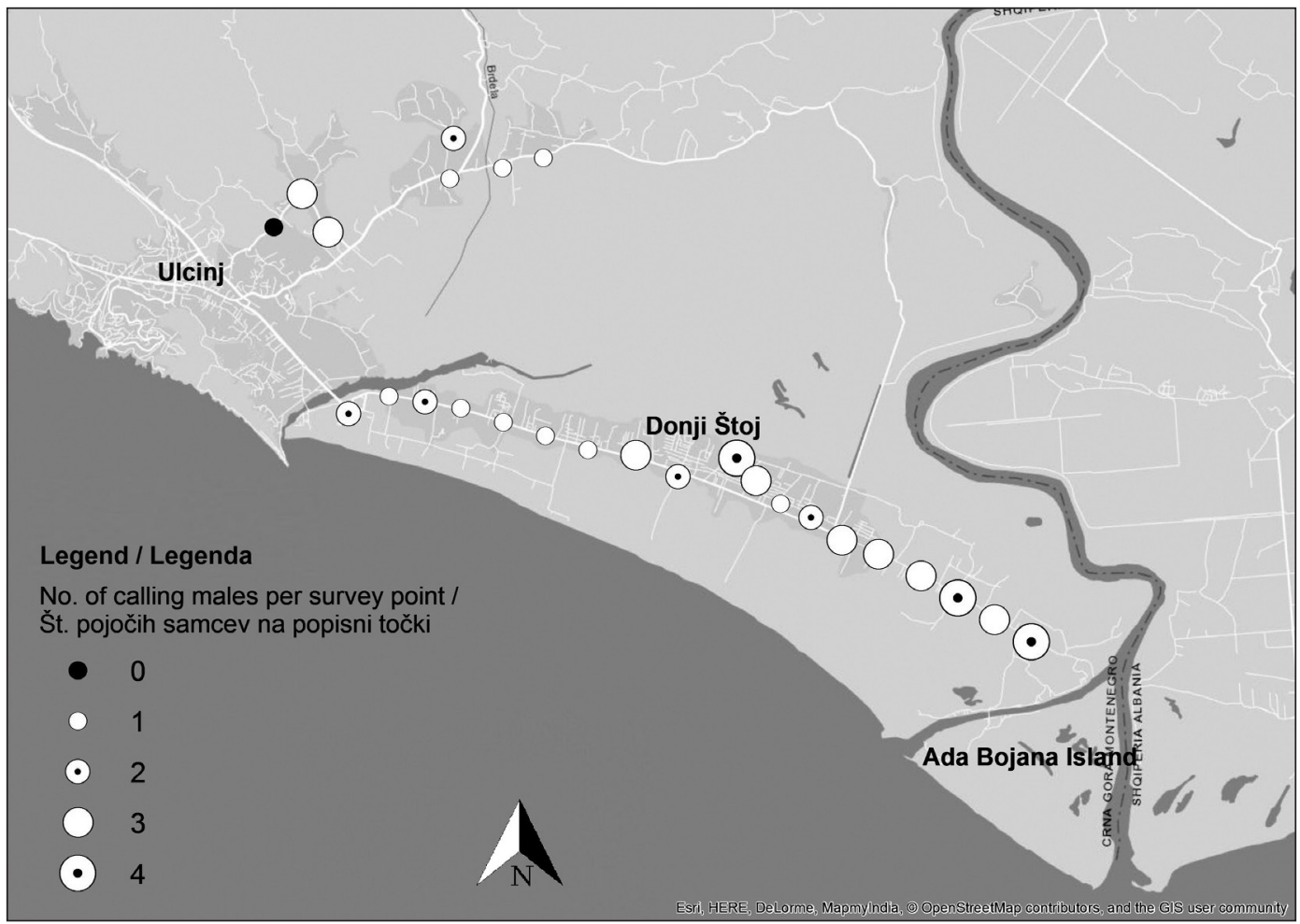

Figure 2: Map of the study area with symbols indicating the number of calling males of Little Owl Athene noctua per survey point

Slika 2: Karta raziskanega območja z označenim številom pojočih samcev čuka Athene noctua na popisnih točkah

The method by Johnson et al. (2007) suggests at least 3 visits to every survey point to be made to determine non-occupancy owing to the low response rate of the species. Nonetheless, due to time limitations and high response by the owls we visited every survey point only once. In the areas of high density, however, the owls responded more readily (Zubergoitia \& CAMpos 1998), so we concluded that repeating surveys would not increase our results substantially. Maps were created using ArcGIS software by Esri.

\section{Results and discussion}

We recorded 55 calling males at the 26 survey points. The density of calling males in the surveyed area was 3.57 per $\mathrm{km}^{2}$. Only one survey point was without a response. On average, we registered 2 calling males per survey point, with the highest number of 4 , which occurred three times.

Centini (2001) concluded that the response rate by the Little Owl to playback was $49.6 \%$. Considering this and the fact that the response rate is higher in the areas more densely populated by Little Owls (Zubergoitia \& Campos 1998), we assume that we registered considerably more than half of the local population. We estimate the local population to be 55-110 calling males.

A comparison of breeding densities from around Europe shows that the Ulcinj area has high local density of breeding Little Owls. Furthermore, it is mostly higher than those in Central and Western Europe (Exo 1992, VogRIN 1997, ILLE et al. 2001, BERCE \& KMECL 2008) and comparable to other studies from the Mediterranean (Hof 2007, Tomé et al. 2008). 
Table 1: Published average Little Owl densities with data on the country, area, unit and reference for the research

Tabela 1: Objavljene povprečne gostote čuka s podatki o državi, območju, enoti in referencah za raziskovanje vrste

\begin{tabular}{|c|c|c|c|c|}
\hline Country & Area & $\begin{array}{l}\text { Singing males/ } \\
\mathrm{km}^{2}\end{array}$ & Pairs/ km² & Reference \\
\hline Italy & Tolfa Mountains, Lazio & & 0.55 & Centili 1995 \\
\hline 1Italy & Pavi & 1.1 & & Cesaris 1988 \\
\hline${ }^{2}$ Slovak republic & Michalovce district & & 1 & Danko et al. 1994 \\
\hline 1,2 Poland & Mazowsze lowland & & 1.4 & Dobrowski et al. 1991 \\
\hline${ }^{2}$ Austria & Burgenland & & 1.5 & Dvorak et al. 1993 \\
\hline${ }^{1}$ Italy & Po plain & & $9,3-11$ & Estoppey 1992 \\
\hline${ }^{1}$ Germany & & $1,2-1,7$ & & Exo 1983 \\
\hline${ }^{2}$ Poland & South Podlasie & & 0.4 & Fronczak et al. 1991 \\
\hline${ }^{1}$ The Netherlands & Betuwe & & 2.1 & Fuchs 1986 \\
\hline${ }^{3}$ France & 10 areas & 0.21 & & Génot 1996 \\
\hline${ }^{3}$ Austria & 5 areas & & 0.08 & Ille et al. 2001 \\
\hline${ }^{1}$ Germany & & & Up to 5,6 & Illner et al. 1989 \\
\hline 1,2 Poland & Kampinos National Park & & 0.6 & Kowalski et al. 1991 \\
\hline Italy & $\begin{array}{l}\text { Plain of Bergamo, } \\
\text { Lombardia }\end{array}$ & & 0.69 & Mastrorilli 1997 \\
\hline Italy & Plain of Pavia, Lombardia & & 0.4 & Pirovano \& Galeotti 1999 \\
\hline Czech Republic & Southern Bohemia & & 0.024 & Pykal et al. 1994 \\
\hline${ }^{1}$ Germany & East-Germany & 0.1 & & Schönn 1986 \\
\hline${ }^{3}$ Czech Republic & 27 areas & & 0.12 & Schröpfer 2000 \\
\hline Denmark & Jutland & & $0,04-0,06$ & Sunde et al. 2009 \\
\hline Hungary & Hortobagy & 0.501 & & Šalek et al. 2013 \\
\hline Italy & Castel Porziano, Lazio & & $3.14-4.62$ & Tomassi et al. 1999 \\
\hline Portugal & Cabeça da Serra & & 7 & Tomé et al. 2008 \\
\hline Portugal & S. Marcos da Atabueir & & 2.5 & Tomé et al. 2008 \\
\hline Portugal & Quinta da Rocha & 6.44 & & Hof 2007 \\
\hline Slovenia & Dravsko polje & & Up to 0,48 & Vogrin 1997 \\
\hline Montenegro & Ulcinj & 3.57 & & This research \\
\hline
\end{tabular}

Little Owls prefer habitats with more buildup areas and less forested areas (Żmihorski et al. 2009). The high density of Little Owls in the surveyed area seems supportive of this finding. Also, many buildings at Donji Štoj are empty during most of the year, since they are occupied only during the summer holidays, meaning lower human disturbance. Additionally, the abundance of meadows and pastures with very low vegetation height in the survey area offer suitable feeding 
places for Little Owls which require areas of low vegetation height or bare ground to spot the prey (GrZYWACZEWSKI 2009, Framis 2011). Surveys in the floodplain of the Bojana River delta $\left(250 \mathrm{~km}^{2}\right)$, which includes the towns of Ulcinj and Štoj, revealed high numbers of other conservationally important insectivorous species such as Scops Owl (Otus scops) $>89$ bp (breeding pairs), Nightjar (Caprimulgus europaeus) 111-500 bp, Roller (Coracias garrulus) 9-15 bp, Hoopoe (Upupa epops) >51 bp and Beeeater (Merops apiaster) >261 bp (SCHNEIDERJACOBY et al. 2006). The relatively high density of Little Owls in the study area corroborates the high biodiversity and conservation value of the Bojana River delta.

\section{Povzetek}

Med 29. 3. in 10. 4. 2015 smo opravili popis čuka Athene noctua $\mathrm{z}$ metodo predvajanja posnetka v južni Črni gori. Preučevano območje je bilo med mestom Ulcinj in delto reke Bojane. Skupno smo zabeležili 55 kličočih samcev na 26 točkah, maksimum za eno točko so bili štirje samci. Upoštevajoč slabo odzivnost vrste na posnetek lokalno populacijo ocenjujemo na 55-110 kličočih samcev. Raziskava je prvi sistematični popis čuka v Črni gori.

Key words: Little Owl, Athene noctua, playback survey method, S Montenegro

Ključne besede: čuk, Athene noctua, metoda predvajanja posnetka, J Črna gora

\section{References}

Berce T., Kmecl P. (2008): Popis čuka Athene noctua na Krasu v letu 2007 - zaključno poročilo. - [http:// ptice.si/2014/wp-content/uploads/2014/04/2008 berce_kmecl_popis_cuka_na_krasu_v_letu_2007. pdf], 08/12/2017

BirdLIFE InTERNATIONAL (2017) Species factsheet: Athene noctua. - [http://www.birdlife.org], 04/12/2017.

Centili D. (1995): Dati preliminari sulla Civetta Athene noctua in un'area dei Monti della Tolfa (Roma). Avocetta 19: 113.

Centili D. (2001): Broadcast and Little Owls Athene noctua: preliminary results and considerations. Oriolus 67 (2-3): 84-88.
Cesaris C. (1988): Popolazioni di Allocco Strix aluco e di Civetta Athene noctua in un'area del Parco Lombardo della Valle del Ticino. - Avocetta 12: 115118.

Cramp S. (1985): The Birds of the Western Palearctic. Vol 4. - Oxford University Press, Oxford.

DANKo Š. (1994): Správa o činnosti skupiny pre výskum a ochranu dravcov a sov v ČSFR za rok 1992. - Buteo 6: 121-151.

Dombrowski A., FronczaK J., Kowalski M., Lippoman T. (1991): [Population density and habitat preferences of owls (Strigiformes) on agricultural areas of the Mazowsze Lowland (central Poland)]. Acta ornithologica 26: 39-54. (In Polish with English abstract).

Dvorak M., Ranner A., Berg H. M., (1993): Atlas der Brutvögel Österreichs. - Umweltbundesamt, Wien.

Estoppey F. (1992): Une densité elevée de Chouettes cheveches, Athene noctua, dans la plaine du Po en Italie. - Nos Oiseaux 41:315-319.

Exo K. M. (1983): Habitat, Siedlungsdichte und Brutbiologie einer niederrheinischen Steinkauzpopulation (Athene noctua). - Ökologie der Vögel 5: 1-40. (In German).

Exo K. M. (1992): Population ecology of Little Owls Athene noctua in Central Europe: a review. pp. 6475. In: Galbraith C. A., Taylor I. R., Percival S. (eds.): The conservation and ecology of European owls: Joint Nature Conservation Committee, Peterborough.

Framis H., Holroy d G. L., Mañosa S. (2011): Home range and habitat use of little owl (Athene noctua) in an agricultural landscape in coastal Catalonia, Spain. - Animal Biodiversity and Conservation, 34.2: 369-378.

FroNCZAK J., DombrowsKI A. (1991): Owls Strigiformes in an agricultural and forest landscape of South Podlasie Lowland (eastern Poland). - Acta Ornithologica 26 (1): 55-61.

Fuchs P. (1986): Structure and functioning of a little owl Athene noctua population. - Annual Reports of the Research Institute of Nature Management (1985): 113-126.

GÉNOT J.C. (1996): Monitoring studies of the Little Owl in France. - The Raptor 24: 24-28.

GrzYwACZEWski G. (2009): Home Range Size and Habitat use of the Little Owl Athene noctuain East Poland. - Ardea 97(4): 541-545.

Hof (2007): Monitoring the Little Owl Athena noctua on Quinta da Rocha. pp. 3-9. In: Simonson W. (ed.), A Rocha Portugal Observatory Report, 2005-06. Associação A Rocha, Portimão.

ILLE R., GRINSCHGL F. (2001): Little Owl (Athene noctua) in Austria. Habitat characteristics and population density. - Ciconia 25: 129-140. 
ILLNER H. (1988): Long-term decrease of the owls Tyto alba, Asio otus, Athene noctua and Strix aluco in an agricultural area in central Westfalia (West Germany) 1974-1986. - Vogelwelt 109: 145-151.

Johnson D. H., VAn Nieuwenhuyse D., GÉnot J. C. (2007): Survey Protocol for the Little Owl (Athene noctua), October 2007 version. - [http://www. globalowlproject.com/protocols/Survey_Protocol_ for_the_Little_Owl.pdf], 06/12/2017.

Kowalski M., Lippoman T., Oglechi P. (1991): Census of owls Strigiformes in the eastern part of Kampinos National Park (Central Poland). - Acta Ornithologica (Warsaw), 26: 23-29.

Mastrorilli M. (1997): Popolazioni di Civetta (Athene noctua) e selezioni dell'habitat in un'area di pianura della provincia di Bergamo. - Riv. Mus. Civ. St. Nat. "E. Caffi" Bergamo 19:15-19.

Pirovano A., Galeotti P. (1999): Territorialismo intra - e interspecifico della Civetta Athene noctua in provincia di Pavia. - Avocetta 23:139.

PyKal J., KrafKa Z., Klimeš Z. (1994): [Population density of the little owl (Athene noctua) in selected regions of the southern Bohemia (Czech Republic)]. Sylvia 30: 59-63. (in Czech)

Sackl P., Bordjan D., Basle T., Božič L., Smole J., Denac D., ŠTUMBerger B. (2016): Spring migration of ducks in the Bojana-Buna Delta - a comparison of migration volumes and conventional count information for a key wetland site within the Adriatic Flyway. In: SACKL P., Ferger. W. (eds.): Adriatic Flyway - Bird Conservafion on the Balkans. Euronatur, Radolfzell.

Saveljić D., JovićEvić M. (2015): Popis ptica Crne Gore sa bibliografijom. - Centar za zaštitu i proučavanje ptica, Podgorica.

Schneider-Jacoby M., Schwarz U., Sackl P., Dhora D., Saveljic D., ANd Stumberger B. (2006): Rapid assessment of the Ecological value of the Bojana-Buna Delta (Albania/Montenegro). Euronatur, Radolfzell.

SснӧnN, S. (1986): Zur Status, Biologie, Ökologie und Schutz des Steinkauzes (Athene noctua) in der D.D.R. - Acta Ornithoecologia 1: 103-133.

SCHRÖpfer L. (2000): Sýček obecný (Athene noctua) v České republice - početnost a rozšíření v letech 1998 - 1999. - Buteo 11: 161-174.

SChwartz U. (2010): Habitat Mapping of the Livanjsko Polje (BA), the Neretva Delta (HR, $\mathrm{BA})$, and Lake Skadar-Shkoder (ME, AL). In: Denac, D., Schneider-Jacoby, M. Stumberger, B. (EDs.): Adriatic Flyway - closing the gap in bird conservation. Euronatur, Radolfzell.

Stumberger B., Sackl P., Saveljić D., SchneiderJaCoBy M. (2008): Management Plan for the Conservation and Sustainable Use of the Natural Values of the Privately Owned Nature Park "Solana Ulcinj” Montenegro. - Joannea Zoologie 10: 5-84.
Sunde P., Thorup K., Jacobsen L. B., HolsegårdRasmussen M. H., Ottessen N., Svenné S., Rahbek C. (2009): Spatial behaviour of little owls (Athene noctua) in a declining low-density population in Denmark. - Journal of Ornithology 150: 537-548.

Šálek M., Chrenkova M., Kipson M. (2013): High population density of Little Owl (Athene noctua) in Hortobagy National Park, Hungary, Central Europe. - Polish Journal of Ecology. 61: 1-165.

Tomassi R., Piattella E., Manganaro A., Pucci L., RanazZi L., Fanfani A. (1999): Primi dati su dieta e densità della Civetta Athene noctua nella Tenuta Presidenziale di Castelporziano (Roma). - Avocetta 23:159.

Tomé R., Cantry P., Bloise C., KorpimäKki, E. (2008): Breeding density and success, and diet compisotion of Little Owls Athene noctua in steppe-like habitats in Portugal. - Ornis Fennica 85: 22-32.

Van Nieuwenhuyse D., Génot J. C., Johnson D. H. (2008): The Little Owl - conservation, ecology and behavior of Athene noctua. - Cambridge University Press, New York.

Zubergoitia I., Campos L. F. (1998): Censusing owls in large areas: a comparison between methods. Ardeola 47-53.

Żmihorski M., Romanowski J., Osojca G. (2009): Habitat preferences of a declining population of the little owl, Athene noctua in Central Poland. - Folia Zoologica 58(2): 207-215.

Vogrin M. (1997): Little Owl (Athene noctua): a highly endangered species in NE Slovenia. - Buteo 9: 99102.

Prispelo / Arrived: 22. 1.2018

Sprejeto / Accepted: 4. 1. 2019 